

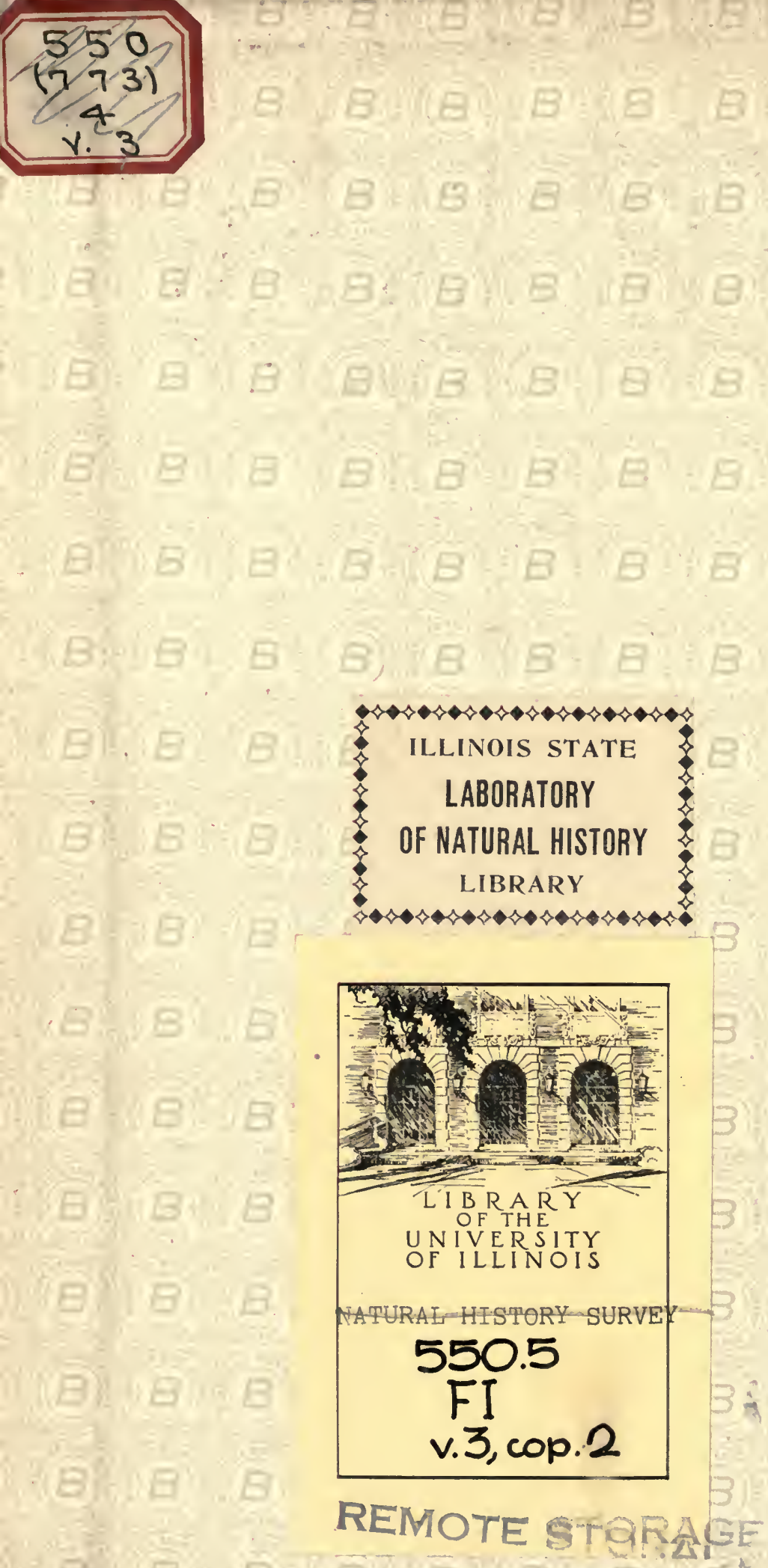

LIBRARY

UNIVERSITY OF ILLNOUS

Un:? 
Field Columbian Museum.

\title{
Publication iog.
}

Geological Series.

VOL. III, No. 2.

\section{THE \\ SHELBURNE AND SOUTH BEND METEORITES.}

\author{
BY \\ Oliver Cummings Farrington, Ph. D. \\ Curator, Department of Geology.
}

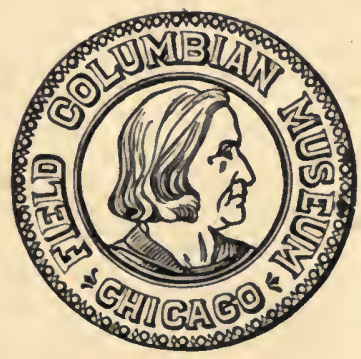

Chicago, U. S. A.

February I, 1906. 

THE SHELBURNE METEORITE.

\section{BY OLIVER CUMMINGS FARRINGTON.}

The Shelburne meteorite fell about three miles from Shelburne, Ontario, at 8 P. M. August I3, 1904. Two stones were obtained from the fall, one of which weighed $12.6 \mathrm{~kg}$. $(273 / 4 \mathrm{lbs}$.) and the other $5.6 \mathrm{~kg}$. (12 $1 / 4 \mathrm{lbs}$.). The latter of these stones came into the possession of his Museum, where it is preserved under the Museum number, Me. 606 .

The general phenomena of the fall and the larger stone have been described by Borgstrōn** (Trans. Royal Astronomical Society of Canada, 1904, pp. 69-94). It remains to describe the smaller stonc and give some additional general observations regarding the fall. The distance between the points of fall of the two stones was about three-quarters of a mile and the direction between them a southeastnorthwest one, the smaller stone being at the southeast. The latter stone fell within eighteen inches of the rear porch of the residence of Mr. John Shields. The phenomena of the fall, as stated by Mr. Shields to the writer, were that sounds like a muffled drum-beat were heard by various members of the family who were in the house at the time, followed by a dull thud at the rear of the house. A man at the barn, two or three rods west of the house, also saw a momentary light. Mr. Shields' impression from the noise was that an old shed in the rear of the house, shown in Fig. $\mathrm{r}$, had fallen. He accordingly investigated to see if this were true. The shed proved to be intact, but a hole newly made was noticed in the soil near it. It was also noticed that the side of the house south of the hole was splashed:with mud. No one investigated farther at the time, but on the morning of the second day (August I5) Mr. Shields dug into the hole and at a depth of eighteen inches* found the stone here to be described. A portion of a burdock leaf, which had evidently been carried into the hole with it, lay under the stone. This showed no evidence of charring or burning. depth.) 
The character of the soil in which the meteorite fell was clayey. and no other stones were observed while digging it up. The meteorite lay with the side shown in Plate V, down. The weather at the time was fair, but there had been a shower a few hours previous. The mud splashed by the meteorite against the house was seen by the writer when he visited the locality six months after the fall, in February, I905. The mud had been thrown in considerable quantity across the porch, a distance of about three feet, upon a

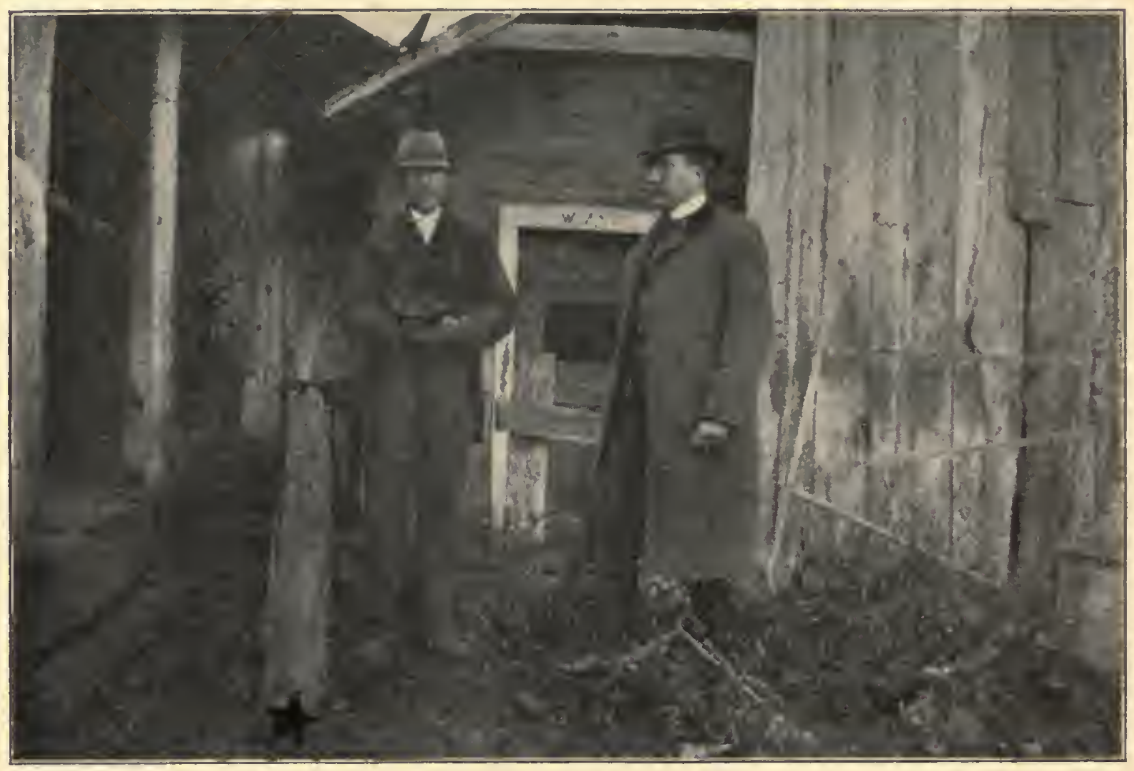

Fig. 1. Place of fall of the Shelburne meteorite. A board marked by the star stands in the hole from which the meteorite was dug.

window, and was even to be seen on the lower side of the roof of the porch at a height of about eight feet. The direction in which the mud was thrown was southeast from the point where the meteorite fell. The shed shown in Fig. I, was six and a half feet from the point of fall. The height of this shed is twelve feet. It stands north of the house, and northwest of the point of fall of the meteorite. A line drawn to the point of fall of the other stone would pass directly over the roof of this shed so that had the direction of fall of the smaller stone been at a low angle with the horizon, it would have struck the roof. Calculation shows that the angular altitude of the meteorite must have been at least $26^{\circ}$ to 
allow it to clear the shed, if it came from the northwest. If its movement was in the opposite direction, $i$. $e$. toward the northwest, it must have fallen nearly vertically to have avoided striking the roof of the porch. This fact, together with the noticeable throw of mud to the southeast, indicates that the path of the meteor was toward the southeast. If this view be correct, the larger stone fell first, which is contrary to the usual rule, and, contrary to what would be expected, since the greater momentum of larger stones usually carries them farther. It is possible in this case that the bursting of the meteor caused a deviation of motion which brought the larger stone to the ground first. The accounts of those who saw the meteor pass seem to be of no value for determining the direction of motion: In the reports quoted by Borgström four observers assert that the meteor was traveling northwest and three that it was traveling southeast. A similar conflict of opinion was found by the writer to exist among those at Shelburne who saw the meteor. A point on which all witnesses agreed, however, was that several reports were heard, at least as many as three. This would indicate that the meteorite broke into more pieces than were found.

The stone found by Mr. Shields, and now in the possession of the Museum, has a shape resembling that of a flat-iron. Its length is ro inches $(25 \mathrm{~cm}$.), its width $5 \mathrm{r} / 2$ inches ( $14 \mathrm{~cm}$.) and its thickness 3 inches $(8 \mathrm{~cm}$.). The several surfaces show differences of crust and rugosity, which indicate the orientation of the meteorite. Thus, of the broad surfaces, one, that shown in Plate VI, is smooth, and has only broad, shallow pits. This was the surface found uppermost when the meteorite was dug up, and is plainly the rear side of the meteorite. The opposite surface, shown in Plate $\mathrm{V}$, is for the most part peppered with small, irregular pits and the crust is thinner. It is not as smooth as the side previously described. It seems evident from the character of the crust and the pittings that not only was this the front side of the meteorite in falling, but that a piece corresponding in outline to the rough portion was split off during the fall. On the lower side of the surface in the position in which the meteorite stands in Plate $\mathrm{V}$, the interior of the meteorite is seen, over two areas, each covering about a square inch. Of these areas the one at the right was produced by a piece having been chipped off for examination when the meteorite was first found. The one at the left, triangular in shape, is a natural scaling which, since it is not encrusted, must 
have been made about the time the meteorite struck the earth. It passes along the plane of a nickel-iron-troilite vein such as appears in other parts of the meteorite, and the position of this vein doubtless determined the fracture. Of the narrow surfaces of the meteorite, one, that shown in Plate VII, has a rugose character and incomplete crust similar to that of the front side of the meteorite. Here, evidently, the meteorite split off from some other mass during its descent to the earth. The other narrow surfaces, shown in Plate VIII, have a complete crust and rounded edges. Their pittings are few and irregular and show rounding and smoothing.

By means of a cast of the larger stone, kindly furnished the Museum by Dr. Borgström, it was possible to determine in what manner the two stones may have been joined together. The rear and front sides are so plainly marked on both stones and the surface of mid-atmospheric fracture so evident in the smaller one that there is little difficulty in deciding that the stones were joined together in the manner indicated in Plates IX and $\mathrm{X}$. Of these, Plate IX shows what, in the view of the writer, was the front side of the meteorite in its descent and.Plate $\mathrm{X}$ the rear side. This determination does not however, accord with that of Borgström; for the larger stone. Borgström reverses them,* basing his determination chiefly on the fact that on what he regards as the rear side, the apparent directions of flow of molten matter point in a general way toward the center of the mass. These directions of flow are determined by a heaping of the crust on the sides of the pits. Such indications, however, are liable to be deceptive. Several pits on the smaller stone show drift phenomena in one direction or another which, in the present writer's view, are to be regarded as remains of flows from the centers of the pits outward. These flows probably take place in all directions but leave traces only here and there. All the other characters of the side regarded by Borgström as the rear one seem without question to be those of the front. It has a generally arched or conical character, a relatively large extent of surface, and deep pits. These are well known characters of the front side of oriented meteorites. Moreover, if this were regarded the rear side, the side which must be taken for the front is one having a form concave toward the direction of movement through the air. It is hardly conceivable that the mass could have come through the air with its concavity foremost. The form obtained by joining the two stones 
together in the manner indicated in Plates IX and X is a somewhat conchoidal one, indicating a scaling off from a larger mass. Such a form, as is well known, is exhibited by other meteorites, notably that of Butsura among stones and Cañon Diablo among iron meteorites. Such a form would be especially liable to fracture during descent. Borgstrom remarks that the larger stone is characterized by concave surfaces. This is also true of the smaller one, and of Butsura as well. The two parts when placed together in the manner indicated in Plates IX and X correspond perfectly as regards front and rear sides. The rear side of each is concave, smooth, and has broad, shallow pits. The front side is concave, rough, and has small, deep pits.

The pittings of the two surfaces of the smaller stone shown in Plates V and VII differ in character from those of the other surfaces. These surfaces may be said to be rougher than the others in the sense that the roughness is due to a greater abundance and smaller size of the pittings. The shape of the pittings is irregular, but in general, saucer-like with diameters of .5 to I centimeter. On the face shown in Plate VII the pittings tend to become elongated in character, with the long axes parallel with the long direction of the surface. The edges which both these rough surfaces make where they join the other surfaces of the meteorite are much sharper than the edges of other parts of the meteorite. These sharper edges and roughness indicate less exposure to fusion and erosion, and therefore a mid-atmospheric fracture along these surfaces. The largest pits on the meteorite are on the surfaces shown in Plate VIII. One depression here shows an area of about $3 \times 3 \mathrm{~cm}$. and a depth of $\mathrm{I} \mathrm{cm}$. Secondary pits break the configuration of this, but all have sloping, rounded edges, showing fusion and erosion during the entire aërial passage of the meteorite. The depressions on the rear side, that shown in Plate VI, are still broader and shallower in character and blend in with the general surface so as to nearly lose the character of pits.

The crust of the meteorite is uniformly black in color. While in general smooth in appearance, it is seen even with the naked eye to be dotted over with minute grains rising above the general surface. These are for the most part protruding metallic grains whose bright surface can be discovered by filing. Besides these the crust may be seen under a lens to be abundantly stippled with clots and threads which anastomose and blend with one another, producing hollows and elevations. The threads rarely extend more than a few milli- 
meters independently and are usually very minute. The appearance of the substance of the crust is like that of black obsidian, being black, opaque and of pitchy luster. The crust adheres firmly throughout to the interior, showing no tendency to scale. There is a noticeable uniformity in the direction in which the threads of fused matter run on the different faces. Such directions are shown in some of the photographs, notably Plates V and VII. In the face shown in Plate VII it is observable that the drift is in the direction of greatest length along the middle line, with diversions to the rear side. If a feather, the barbs of which had been removed from one side of the midrib, were laid along the surface the directions of the remaining barbs would indicate quite accurately the directions of drift. The drift on this face may therefore be described as pinnate. On the face shown in Plate $V$ there is drift radiating from the center outwards. On the face shown in Plate VI, or rear side of the meteorite, the drift tends to follow the direction of greatest length, though modified by radiation outward from the pits.

The crust studied in thin section under the microscope shows nearly all the zones described by Borgström. The first, third, and fourth are manifest, but the second zone, or "thin brownish layer," which he describes, is not visible in any of the sections which the writer has examined. The failure of this zone to appear may be due to the thickness of the sections, but if so it would require unusually thin sections to show it. The intervention of the colorless, or third, zone between the dark first and fourth zones is a striking phenomenon and lends a high degree of probability to Borgström's view that the fourth zone is due to alteration of interstitial glass rather than to a penetration of molten matter from the surface. The thickness of the several layers, as observed by the writer, accords with that noted by Borgstrom, except in the maximum thicknesses which he quotes. The total crust on the small stone is rarely more than $.3 \mathrm{~mm}$. in thickness. Fragments of the meteorite heated B. B. turn black, shading to red distant from the flame and fuse on the edges to a black slag.

The meteorite as received at the Museum was penetrated by several small cracks extending in a general way at right angles to its broad surfaces. The courses of some of these can be seen in Plate V. Mr. Shields, finder of the meteorite, states that he noticed them the second day after digging the stone up. They probably indicate therefore a partial shattering of the meteorite due to its 
impact upon the earth. Borgström has calculated from the depth of the hole which the meteorite made in the earth that the velocity with which it struck was one of ${ }_{5} \mathrm{I}_{5}$ feet ( ${ }_{57} \mathrm{~m}$.) per second.* This is equal to the velocity which a body falling in a vacuum would acquire in 4600 feet.

The substance of the meteorite as a whole is fairly coherent, crumbling slightly under pressure by the fingers, but only slightly. It is sufficiently coherent to take a good polish. The specific gravity of the meteorite was determined in three ways, the determinations being made by Mr. H. W. Nichols. The first two determinations were made with a view to finding the apparent specific gravity, by which the porosity of the stone is shown. This determination was made in two ways. First, a cast of the meteorite was immersed in a vessel full of water, and the weight of the water thus displaced compared with that of the meteorite. This gave $\mathrm{G}=3.288$. For the second determination the volume of the meteorite was determined by comparing the weight of a cube of unit size made of the same plaster as the cast with the weight of the cast. The weight of an equal volume of water compared with the weight of the meteorite gave $\mathrm{G}=3.278$. The third determination was made by the ordinary method of comparing the weight of a piece of the meteorite immersed in water with the weight of the same in air. From a slab of the meteorite weighing 480 grams and partially bordered with crust, the specific gravity obtained by this method was $\mathrm{G}=$ 3.504. This corresponds almost exactly with the result obtained by Borgström, which was $G=3.499$. Comparison of a mean of the two values for apparent specific gravity with the specific gravity as determined by the ordinary method, shows, using the formula given by King $\dagger$ the porosity of the meteorite to be 6.3 per cent.

The interior of the meteorite is in color light ash-gray, flecked with rusty-brown about the metallic grains, which are nickel-white to brass or bronze-yellow. Numerous circular spots of light and dark gray color indicate chondri. Those of dark gray are generally enstatite, those of light gray chrysolite. The diameter of the chondri sometimes reaches $6 \mathrm{~mm}$. The metallic grains are for the most part rather uniform in size and distribution, appearing as metallic points scarce exceeding $\mathrm{I} \mathrm{mm}$. in any dimension. They may consist of nickel-iron alone, troilite alone or an aggregate of these. The two components may be readily distinguished by color.

* Op. cit. p. 75.

† Agricultural Physics p. Ir 5. 
In several instances a tendency to a ring-like form is observable, the diameters of such rings averaging about $2 \mathrm{~mm}$. Aggregation of the metallic matter in the form of veins is also observable, and constitutes an essential feature of the meteorite. These veins appear in section as thin, irregular lines about $.5 \mathrm{~mm}$. in width, while their greatest extent in length noted was 5 inches (i $3 \mathrm{~cm}$.). There are three such veins to be seen in the stone appearing entirely distinct from one another. In a general way they run parallel to the broad surfaces of the meteorite, although their course is tortuous and at times becomes somewhat diagonal to thesesurfaces. They outcrop on the crust surfaces of the meteorite as more or less continuous ridges rising .2 to $.3 \mathrm{~mm}$. above the surface. On the face shown to the left in Plate VIII two such outcrops can be seen nearly parallel with the front side of the meteorite. One of these is about half an inch ( $\mathrm{r} \mathrm{cm}$.) from the edge, and the other about one inch $(2.5 \mathrm{~cm}$.) below the first. As seen in section none of the metallic veins runs entirely through the body of the meteorite. In some sections they appear at the outer edges and disappear in the interior, while in others they appear in the interior but do not extend to the edges. This irregularity of course and extent tends, in the writer's opinion, to confirm his previously expressed view that such veins are phases of structure of the meteorite rather than filled fissures.* The general appearance of two of these veins in section, also the nature of the distribution of the metallic grains in general, is shown in the section represented in Plate XI. Over the triangular surface shown in the lower left hand corner of Plate $\mathrm{v}$, where, as before remarked, a natural scaling along one of the veins has taken place, the substance of the vein could be examined. The appearance of the surface here exposed was one of uniformly bronze-yellow color, there being no differentiation of ingredients according to color. On removing a portion about $2 \mathrm{~cm}$. square, however, and grinding it to a smooth surface, some of the metallic portions showed a nickel-white color while the rest remained bronze-yellow. This indicated that the vein was made up of aggregated nickel-iron and troilite, and this indication was confirmed by further tests. The nickel-iron grains, some of them several square millimeters in area, were subjected to the action of nitric acid in order to determine whether they showed Widmanstätten figures. None appeared, however, although several trials were made. The action of the acid only produced a minute pitting of the surface of the metal. By

\footnotetext{
*Am. Jour. Sci, 4, I r, pp. 60-62.
} 
continued treatment with strong nitric acid the nickel-iron was entirely dissolved out and the troilite was left free. It was found to be chiefly in the form of small elongated and flattened nodules and plates, showing a tendency to faceting at some points, but with no determinable planes. One of these nodules had a length of $3 \mathrm{~mm}$. The separation between these nodules and the nickel-iron seemed complete, there being no intimate intergrowth of the two substances. The troilite was of dark bronze-yellow color, non-magnetic and easily fusible to B. B. a magnetic globule.

The microscopic characters of the meteorite have been quite fully described by Borgstrom, and the features which he points out are essentially duplicated in the sections before the writer. The chondritic structure of the meteorite is very marked, and the chondri exhibit a variety of structures. Especially well represented are those made up of parallel lamellæ of chrysolite and glass. These lamellæ run in different directions in different chondri. In
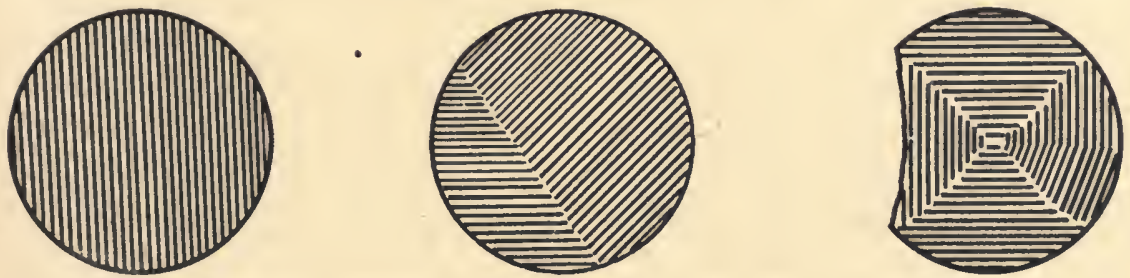

Fig. 2. Diagrammatic representation of arrangement of chrysolite lamellæ in chondri of Shelburne meteorite.

some they are all parallel and, together with the border of the chondrus, extinguish simultaneously. In others they may be found running in two or more directions, in which case those lamellæ which are parallel extinguish simultaneously, but extinctions are different for the different groups. In the accompanying diagrams, Fig. 2, are represented some of the arrangements of lamellæ observed. The first diagram shows a simple single arrangement, the second two sets of lamellæ meeting at angles of $135^{\circ}$, and the third practically two sets of lamellæ meeting at angles of $90^{\circ}$, although on one side the lamellæ are somewhat bent. Extinction in all these forms is parallel to the long axis of the lamellæ. The width of the lamellæ in the chondri of this character is remarkably uniform, and is about .OI $\mathrm{mm}$. The diameter of the chondri themselves is from I to $1.5 \mathrm{~mm}$. When the individual lamellæ are studied with a high magnifying power their apparent continuity in the direction of length resolves itself into two 
or more component lamellæ joined end to end. The ends of these component lamellæ are usually rounded. The lamellæ are frequently crossed by fractures which usually run normal to the length, but are occasionally more inclined.

Between chondri with a structure of the above character and those which are porphyritic there seem to be all gradations. The stages are: I. Chondri in which the lamellæ are wider and fewer in number; and 2 . Wide lamellæ extending only partially across the chondrus. If the writer is correct in this observation, it is easy to see that differences of extinction do not necessarily prove a polysomatic origin for a chondrus. The lamellæ of each chondrus of the types figured above are doubtless of a single generation, though differently oriented. So the crystals of a single chondrus though differently oriented may be of a single generation. Another arrangement of chrysolite and glass lamellæ which was seen in addition to those noted above was an eccentrically radial one. These lamellæ are wider than those which are parallel. In this case the lamellæ are wedge-shaped, and are enclosed in a glass so dark as to be opaque. In the porphyritic chrysolite chondri the crystals were for the most part uniform in size. In one chondrus, however, a large crystal with rectangular outline was seen to occupy the center with smaller ones grouped concentrically about it. In another large chondrus a smaller one was enclosed. In addition to its occurrence in chondri chrysolite is to be found in individual crystals scattered through the mass of the meteorite. These crystals usually do not appear to be formed in place, but to be fragments consolidated with the chondri. They show no signs of decomposition or wear, and are free from inclusions. In outline they are rectangular to polygonal, and in length measure from .2 to $.5 \mathrm{~mm}$.

The enstatite chondri show little variation from the usual fanshaped forms. The individual fibers in these forms, however, are usually much less distinct than the individual lamellæ of the chrysolite chondri. In one enstatite chondrus an appearance of a system of fibers crossing the main system at right angles was found on study with a higher power to be due to a textural change across the fibers along these lines. Such a change suggests strain. Large individual crystals of enstatite occur, the largest noted being lath-shaped and having a length of $4 \mathrm{~mm}$. and a width of $2 \mathrm{~mm}$. This is truly a remarkable size when compared with that of the general constituents of the meteorite. The outlines of this crystal were irregular, yet it was sharply separated from the surround- 
ing field. Its interior was somewhat corroded and honeycombed, from what cause does not appear. It showed cleavage in two directions to which extinction was parallel.

In connection with the occurrence of troilite in the meteorite, it may be noted that one chrysolite chondrus showed grains of troilite, scattered about its periphery and a vein of the same mineral extending diametrically across it.

Acknowledgments are due Dr. C. A. Chant, of the University of Toronto, and the late Arthur Harvey, Esq., of Toronto, for information kindly given regarding the meteorite. 



\section{THE SOUTH BEND METEORITE.}

\section{BY OLIVER CUMMINGS FARRINGTON.}

This meteorite was found in the spring of 1893 on a farm about two miles southeast of the city of South Bend, St. Joseph County, Indiana. The location of the point of find is $86^{\circ} \mathrm{I} 5^{\prime} \mathrm{W}$. and $4 \mathrm{I}^{\circ}$ $38^{\prime} \mathrm{N}$. The township in which the find was made is not Portage township, in which South Bend is located; but the next one east, Penn township. On account, however, of the close proximity to the well-known city of South Bend it seems advisable to call the meteorite by this name. The place of find was a slope of one of the morainic hills which characterize the area, and the meteorite was discovered when plowing the soil. It attracted attention as a curious stone and was therefore thrown upon a pile with other curious stones, there to lie until its meteoric nature was detected in the fall of 1904 by Mr. George A. Baker of South Bend, Secretary of the Northern Indiana Historical Society. From Mr. Baker the entire mass was obtained for the Museum. Its weight when obtained was $5 \frac{1}{2}$ pounds $(2,374$ grams).

The meteorite is seen at a glance to be made up chiefly of iron and chrysolite, and to be therefore a pallasite.

The shape of the mass may be approximately described as like that of a baby's shoe. This resemblance is perhaps best. shown by the side view given in Plate XIII. The leg of the shoe, however does not widen toward the top, but narrows and shows a slight twist. Following the simile the dimensions of the meteorite may be given as follows: Length (along sole of shoe), $51 / 2$ inches ( $14 \mathrm{~cm}$.); height (from heel to top of leg of shoe), 5 inches $(\mathrm{r} 3 \mathrm{~cm}$ ); width (of sole of shoe), $3 \frac{1}{2}$ inches (9 cm.); circumference (around sole of shoe), $\mathrm{I}_{5}$ inches $(38 \mathrm{~cm}$.); circumference in direction at right angles to above), $\mathrm{r} 2$ inches $(3 \mathrm{r} \mathrm{cm}$.). The appearance of the meteorite from the side described as the sole of the shoe is shown in Plate $\mathrm{XV}$, and that from the rear of the shoe, showing the curving of the upper portion, in Plate XVI.

As all the plates show, the surface of the meteorite is everywhere deeply pitted, giving the entire mass a porous appearance. The 
pits in general have rounded outlines, and are about half as deep as broad. A diameter of about half an inch ( $\mathrm{I} \mathrm{cm.)} \mathrm{is} \mathrm{common,}$ but occasionally a breadth of one and a half inches $(4 \mathrm{~cm}$.) is reached. At one point the bottoms of two pits on opposite sides meet and produce the perforation shown in Plate XIV. This perforation is about one-fourth of an inch $(5 \mathrm{~mm}$.) in diameter. Another pit above this point produces a similar though smaller perforation. A broader, shallow concavity with subordinate pits occurs upon this same surface. The diameter of the outer rim of this concavity is about three inches $(8 \mathrm{~cm}$.). The other broad surfaces of the meteorite tend to be plane or convex. In addition to the pits, which are confluent at their bases, there are many confluent at their sides, producing irregular, sinuous depressions all over the surface of the meteorite. While these cavities are referred to as pits they should probably not be regarded as due to the aerrial course of the meteorite. On the contrary they are altogether produced, so far as can be judged, by the weathering out of chrysolite from the metallic matrix. That they indicate cavities previously occupied by chrysolite is shown partly by the spheroidal shape of the pits and partly by the remains of chrysolite in some of the pits. The edges of the pits are for the most part rounded so as not to leave sharp, projecting points. Such roundings may well have been caused by fusion during the passage of the mass through the atmosphere. Although the substance of the meteorite is tough and firm as a whole. the surface is considerably rusted and the pits filled to some extent with sand cemented with iron hydroxide. This indicates that the meteorite has been exposed for some years to the elements, but not many, for a moist climate, such as prevails in the region where it was found, would cause rather rapid decomposition. The coating of rust on the projecting ridges and points of the meteorite or in the pits not filled with sand is very thin, a single scratch with a file serving to reveal bright metal beneath. This rust is dark brown in color. Where the pits are filled with cemented sand the color becomes a yellowish-brown. There is no indication in the contour of the mass of its having been subjected to movement and pressure, such as it would have undergone had it been glacially transported. The indications are, therefore, that the mass fell not many years ago near where it was found.

The specific gravity of the meteorite was determined by weighing carefully the entire mass, first in air and then in water. This gave the value $G=4.28$. Assuming the specific gravity of chrysolite 
to be 3.35 and that of nickel-iron to be 7.70 , the ratio of chrysolite to nickel-iron by weight in the meteorite indicated by this specific gravity is:-

Chrysolite........................ 78.63

Nickel-iron........................... 21.37

This result is necessarily too high for the chrysolite and too low for the nickel-iron as regards the original constitution of the mass, on account of the fact that some of the original nickel-iron has altered to limonite, and some of the pores contain more or less sand. What change should be made in the above figures on this account in order to express the actual original composition of the meteorite, however, it is impossible to determine, but it is hardly likely that a change greater than $5 \%$ should be made.

A piece of the meteorite weighing about 220 grams was removed by sawing, giving a section having a surface about 2 inches square available for study. The appearance of this section is shown in Plate XVII. As indicated by the external characters, the interior of the mass proves to be a sponge-like body of nickel-iron, the pores of which are filled with chrysolite. The shape of the pores tends to be rounded or polygonal, but is occasionally elongated or quite irregular. A diameter of about half an inch (12 $\mathrm{mm}$.) is a common one for the pores, and they rarely exceed this. The distribution of the nickel-iron is rather uniformly tenuous but occasionally bunched so as to give a square centimeter of surface without chrysalite. The walls of the pores as seen after removal of the chrysolite are sinuous rather than angular and have smooth surfaces. A black graphitic layer about .I mm. in thickness usually lines the pores, separating the nickel-iron from the chrysolite. A similar layer occurring in the Mount Vernon meteorite has been described by Tassin.* Etching brings out well-defined figures on the nickel-iron showing that it is made up of the usual alloys of kamacite, tænite and plessite. The kamacite bands are swollen and very variable in width, but rarely exceed $2 \mathrm{~mm}$. in this direction. For the most part the bands tend to border the chrysolite blebs, following their outlines in varying course. Bordering the kamacite on the side opposite the chrysolite occurs a thin ribbon of tænite appearing and disappearing without regularity, but for the most part quite constant. The plessite, dark gray in color, fills the spaces between the kamacite bands, resembling in its irregular shapes. the hieroglyphic figures assumed by schreibersite in some of the ataxites. At times its

*Proc. U. S. Nat. Museum, 1905, vol., xxxiii, p. 216. 
structure is comb-like on account of alternating filaments of tænite, but for the most part it is uniform and homogeneous. The nickeliron is malleable but hard.

An analysis of the nickel-iron made by Mr. H. W. Nichols gave the following results :

$$
\begin{aligned}
& \mathrm{Fe}=90.22 \\
& \mathrm{Ni}=9.35 \\
& \mathrm{Co}=0.26 \\
& \mathrm{Cu}=0.1 \mathrm{I} \\
& \mathrm{P}=0.05 \\
& \mathrm{~S}=\frac{0.05}{100.04}
\end{aligned}
$$

Schreibersite forms an accessory constituent of the meteorite, distinguishable from the nickel-iron by its tin-white color and granular surface. At one point in the section examined it is seen uninterruptedly over an area about $4 \mathrm{~mm}$. square. At another point it forms a part of the wall of one of the pores, separating two chrysolite blebs by a space of about I $\mathrm{mm}$. Again it fills about one-fourth part of a pore, the rest of the filling being chrysolite. The occurrence of the schreibersite seems to be independent of the nickel-iron, no swathing kamacite surrounding it. It is brittle, magnetic, and gives the test for phosphorus with ammonium molybdate.

The chrysolite of the meteorite occurs, as previously stated, filling the pores of the nickel-iron. In spite of the smoothness of the walls of the pores the chrysolite adheres firmly to them so as to be removed only with difficulty. The surface of the blebs is usually rounded and none showed angular facets suitable for measurement. The color of the chrysolite is generally dark brown to black, though occasionally a typical olivine green. Often there are variations of color in the same bleb. As a rule, the color is lighter toward the center and grows gradually darker toward the periphery, but occasionally there are sectors sharply separated by being darker or lighter than the remainder of the bleb. Though the blebs generally appear opaque when seen as a whole, fragments the size of a pinhead or larger are usually transparent. Under the microscope such fragments appear clear except for opaque brown or black layers scattered through them. The fragments are often magnetic before heating and always so after heating. The individual blebs are monosomatic as shown by the uniform directions of their cleavages and lack of zonal structure. They are considerably fissured and broken, but not as much so as in the Imilac chrysolite. 
South Bend is the seventh pallasite to be discovered in the United States, the others recognized being Admire, Anderson, Brenham, Eagle Station, Mount Vernon and Port Orford. Of these Anderson is the nearest in locality to South Bend, but it is one hundred and fifty miles distant. In structure, moreover, it differs. In the character of its etching figures and the fissured state of its chrysolite, South Bend resembles the Imilac pallasite more than that of Krasnojarsk. It therefore belongs to the Imilac group, and is the first representative of this group to be found in the United States. To the meteorites of Indiana it adds a sixth, those now known from the State being as follows :

$\begin{array}{llll}\text { Harrison County, } & \text { Stone } & \text { Cho. } & \text { Fell March 28, I859. } \\ \text { Kokomo, } & \text { Iron } & \text { Dc. } & \text { Found } 886 . \\ \text { Plymouth, } & \text { Iron } & \text { Om. } & \text { Found } 893 . \\ \text { Rochester, } & \text { Stone } & \text { Cc. } & \text { Fell Dec. 2I, I876. } \\ \text { Rushville, } & \text { Stone } & \text { Cg. } & \text { Found I866. } \\ \text { South Bend, } & \text { Iron-stone } & \text { Pi. } & \text { Found I893 }\end{array}$

The locations of the points of fall of the above meteorites are shown on the accompanying map of Indiana, Plate XVIII. A noticeable feature of the distribution of these falls is that all but one are along a north and south line close to the meridian of $86^{\circ}$. The three falls known in Michigan, viz: Allegan, Grand Rapids and Reed City, also follow closely the same meridian. 



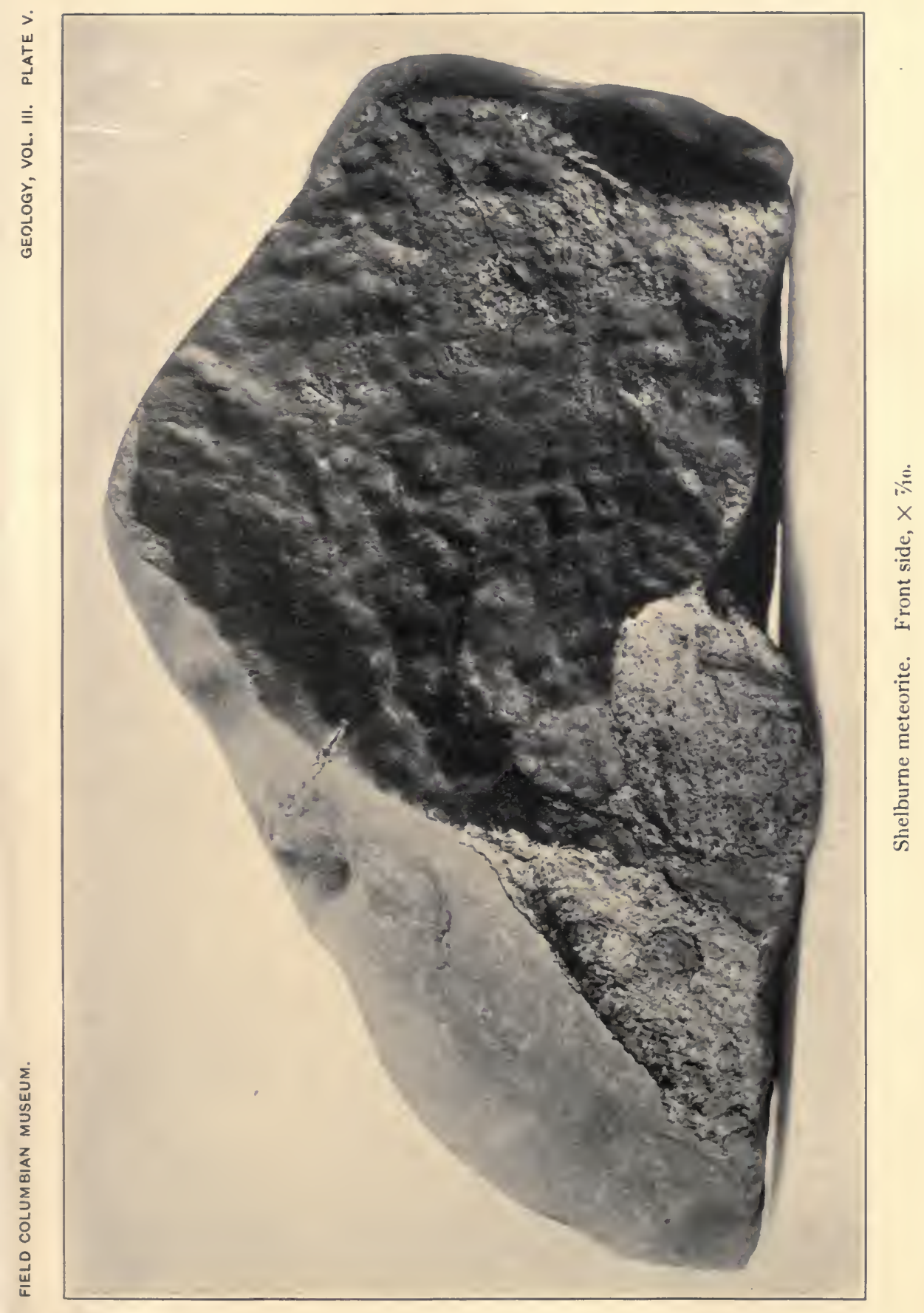


LIBRAR'

UNIVERSIIY OF HL......

yn: 


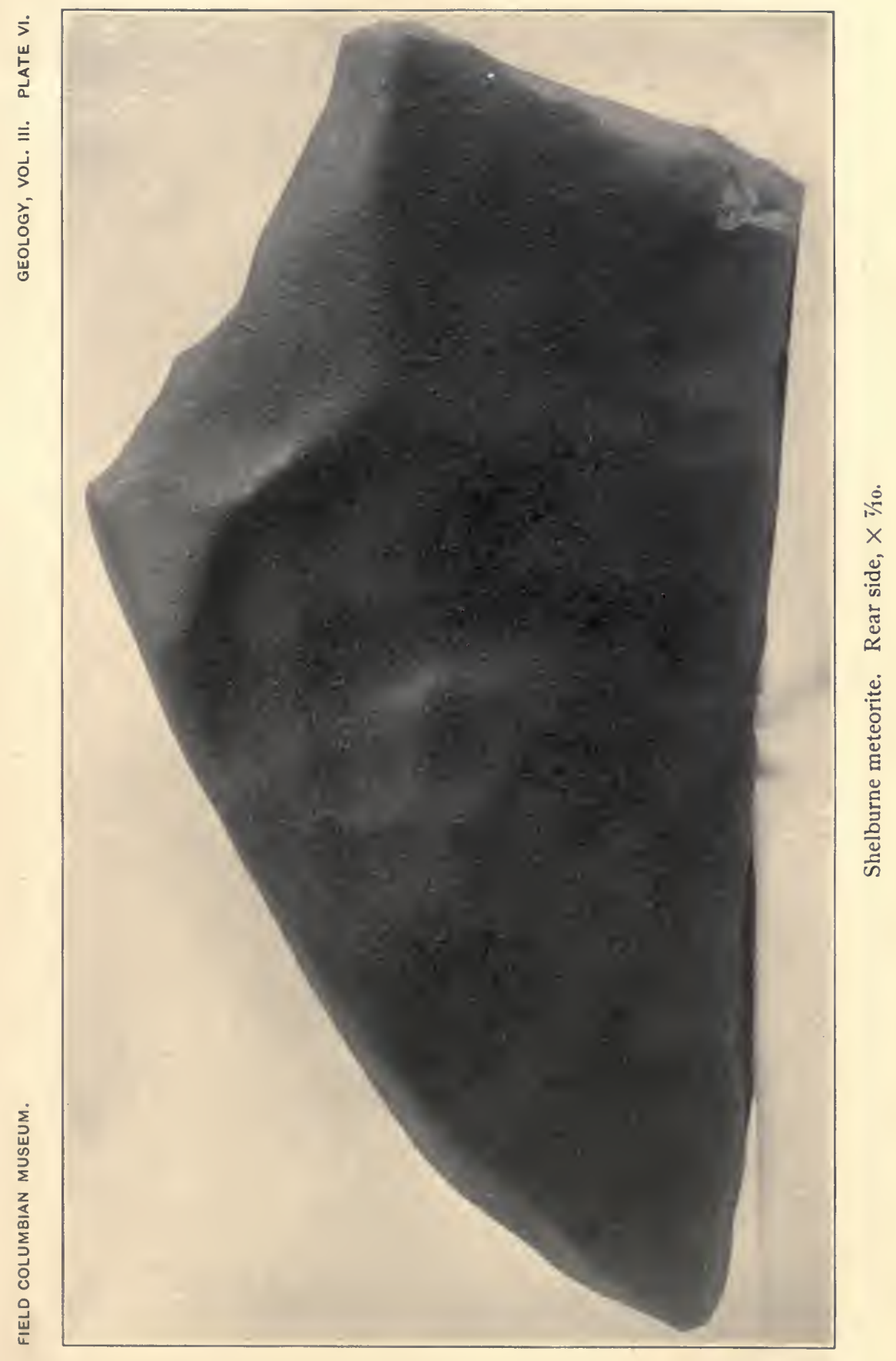


LIBRARY

UNIVERSITY Cf 11 !.:

1ำ..... 


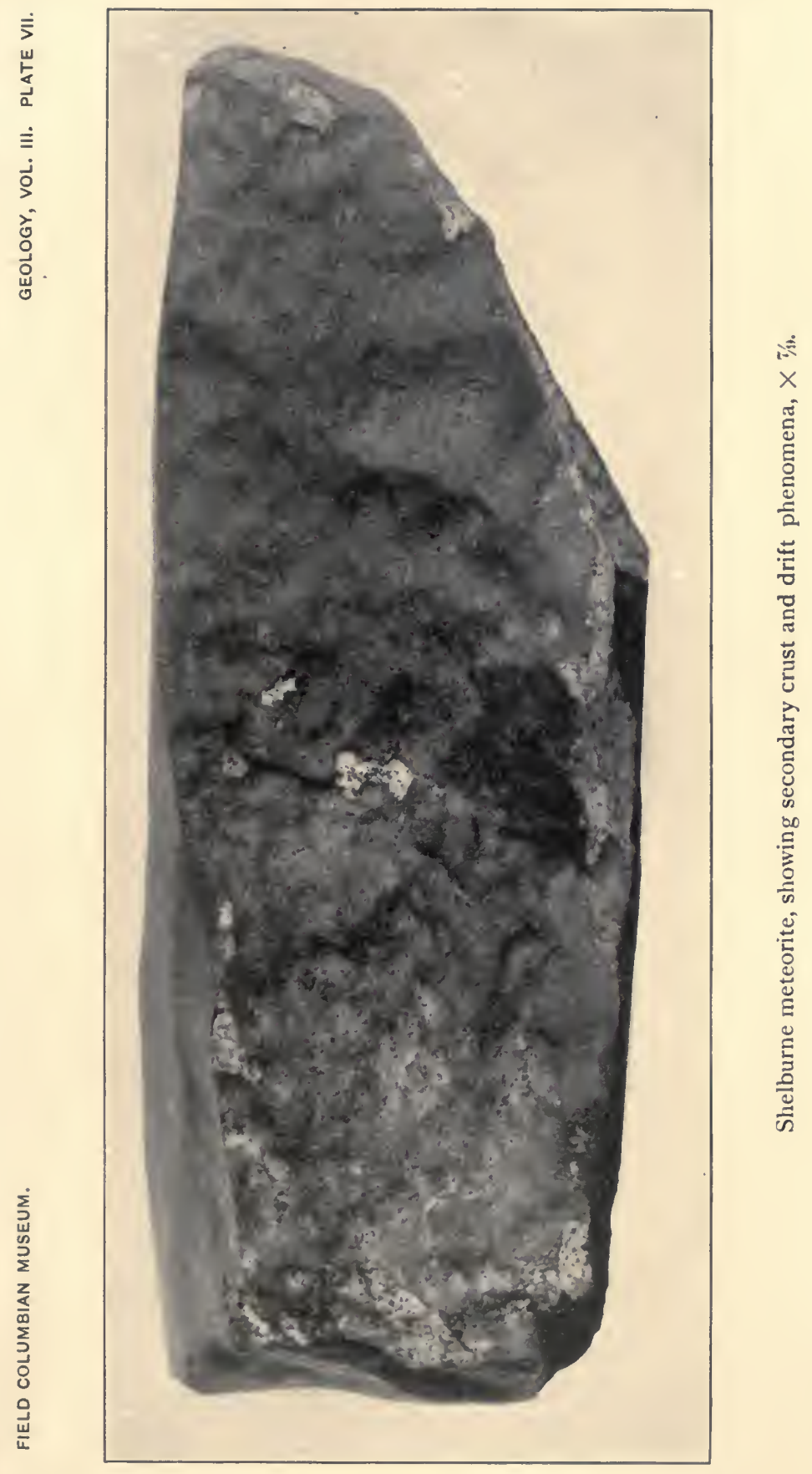


LIBRARY

UNIVERSITY OF ILIINOIS

Unane.1 


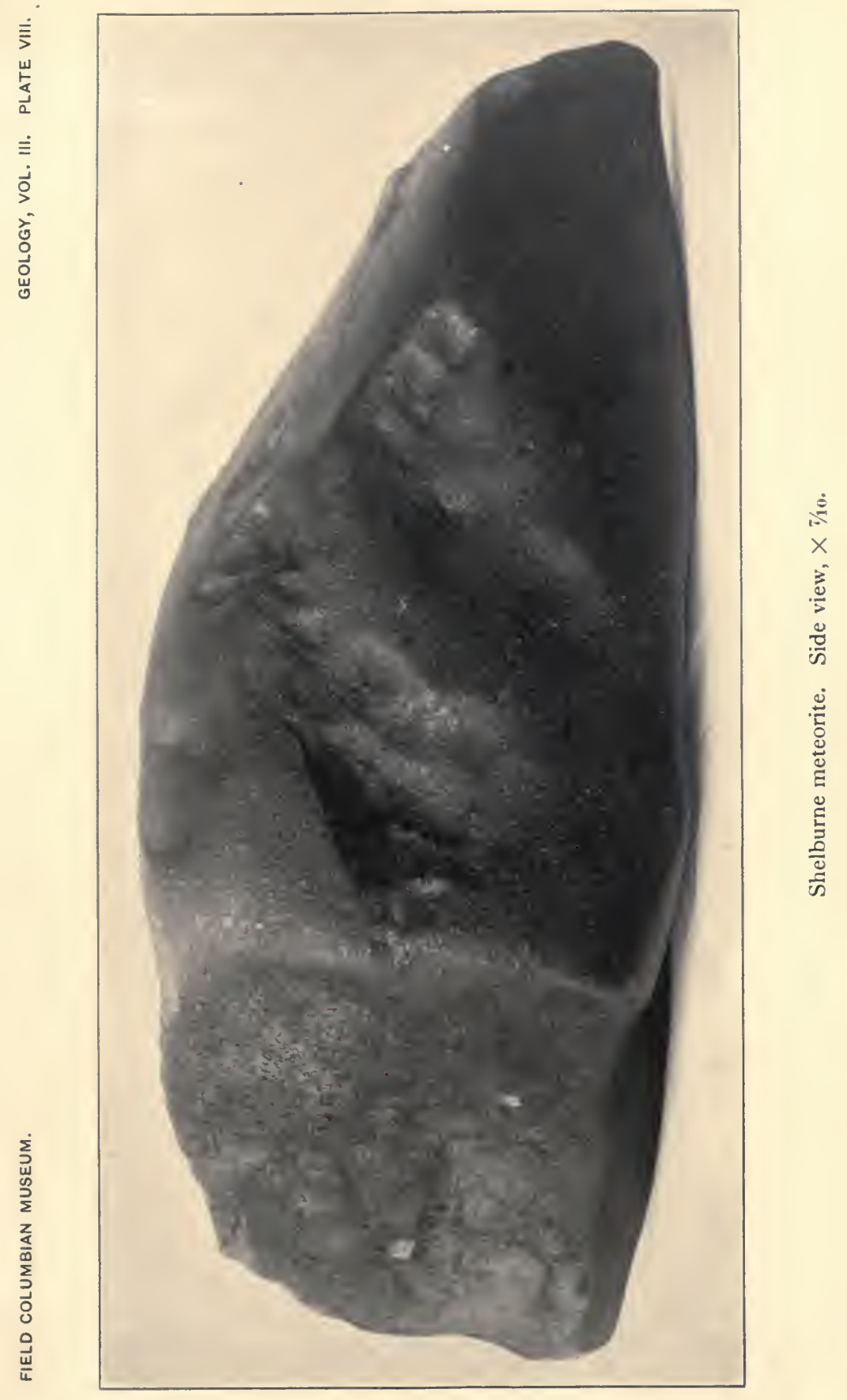


LIBKARYY

UNIVERSIIY OF ILLINUIS

UmBAn 


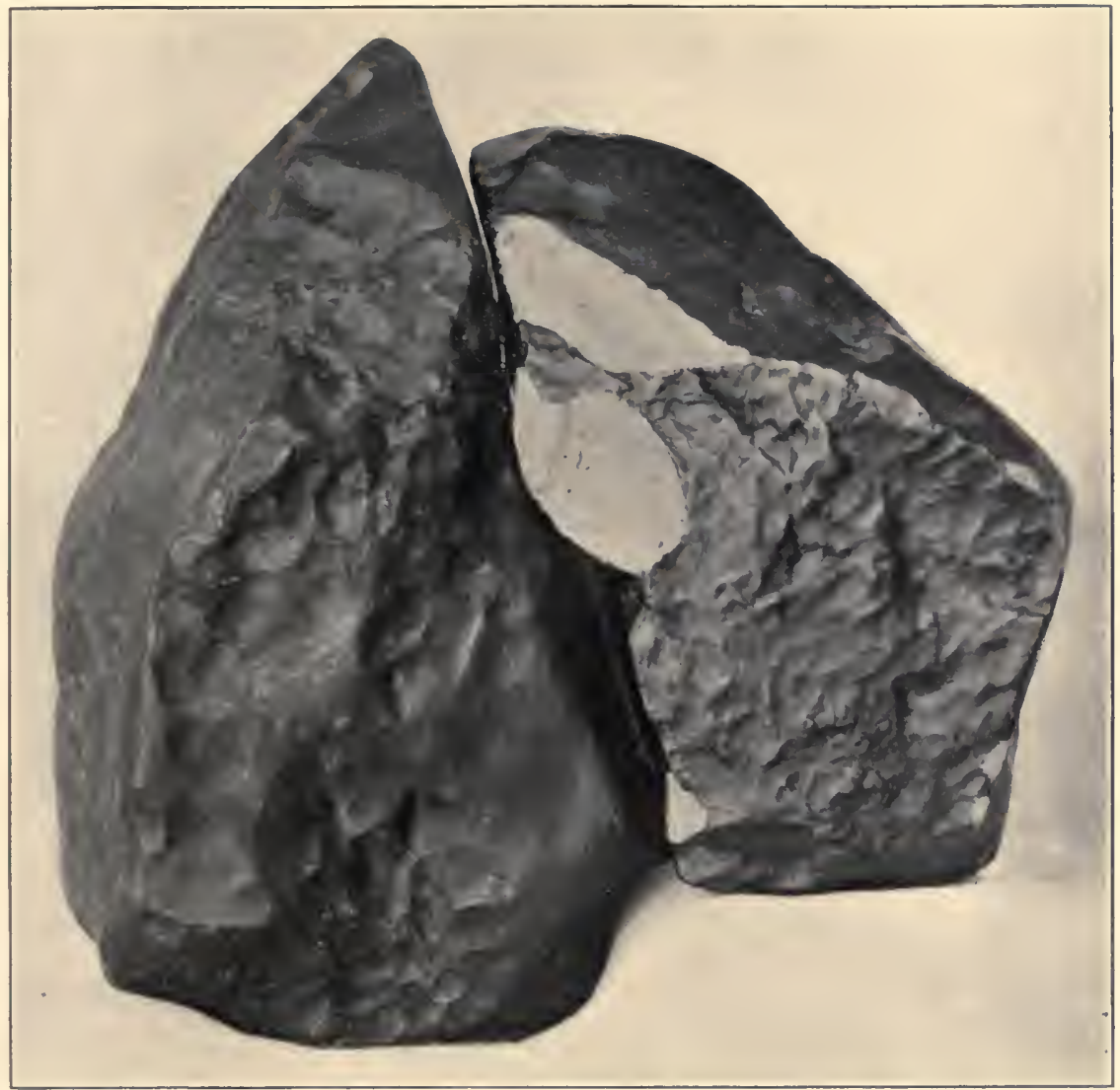

Shelburne meteorite, showing form produced by joining the two stones together. Front side, $\times \%$. 
LIBRARY

UNIVERSITY CF IL!..... ;

!1!7: $: 3.1$ 


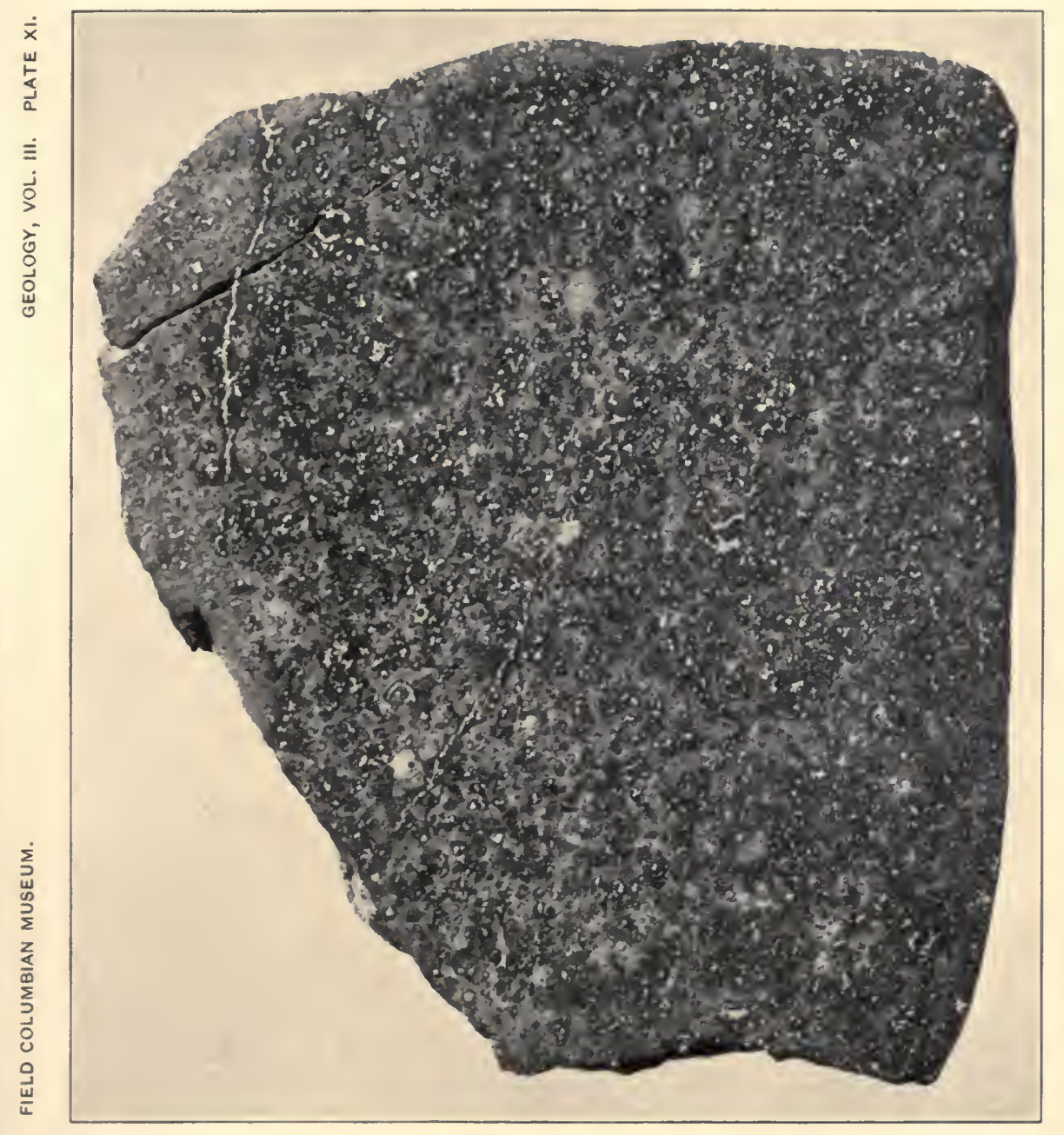

व. 
LIBRARY

UNIVERSITY OF ILUME. J

!?? :....। 


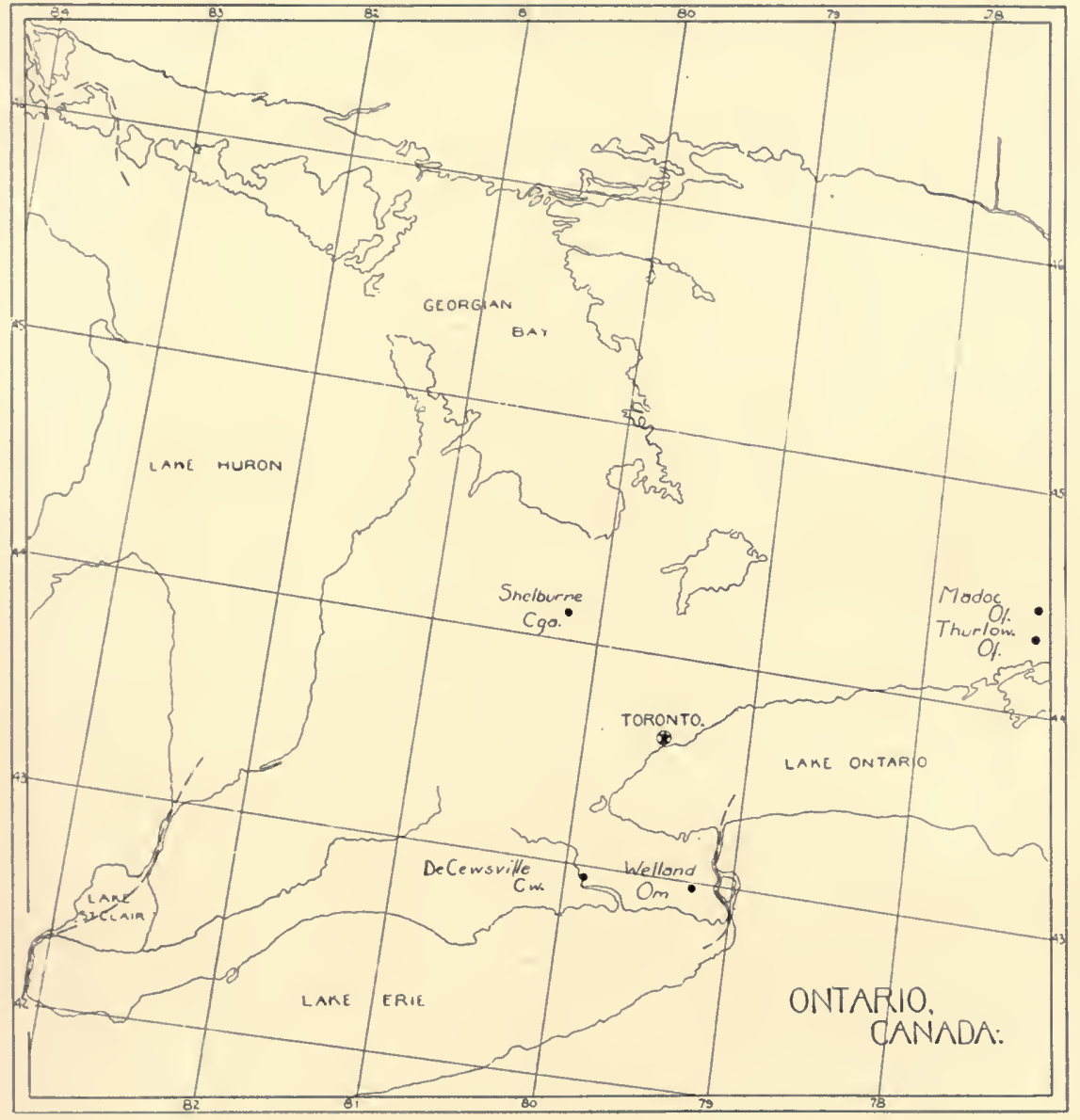

Map of Ontario, showing location of known meteorite falls. 
LIRRARY

UNIERSITV OF ILLANOS

Gen.... 


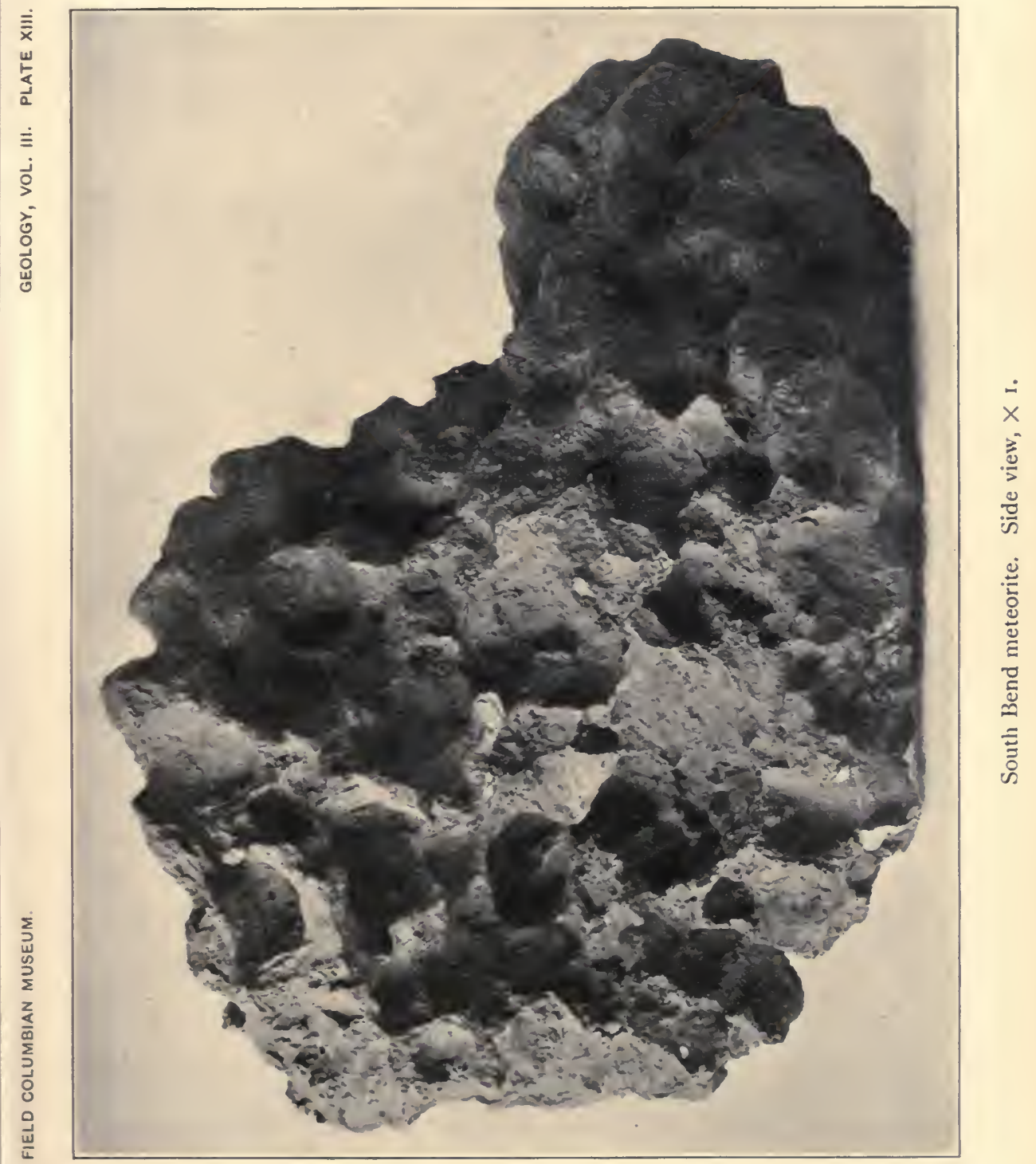


LIBRARY

UNIVERSITY OF ILLINOIS

basarial 


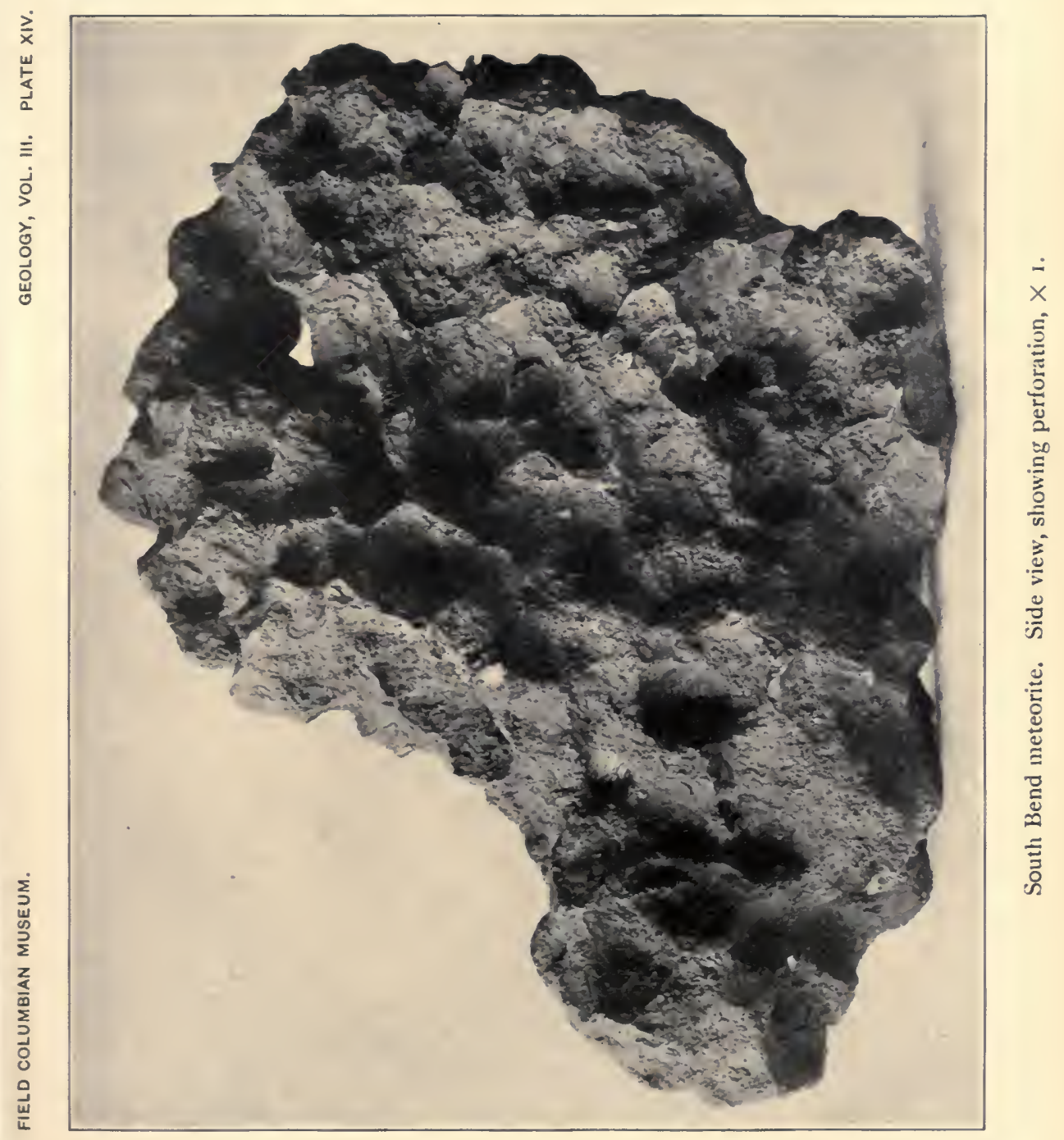


LIBRARY

UNIVERSITY OF ILUINOIS

U20?n: 


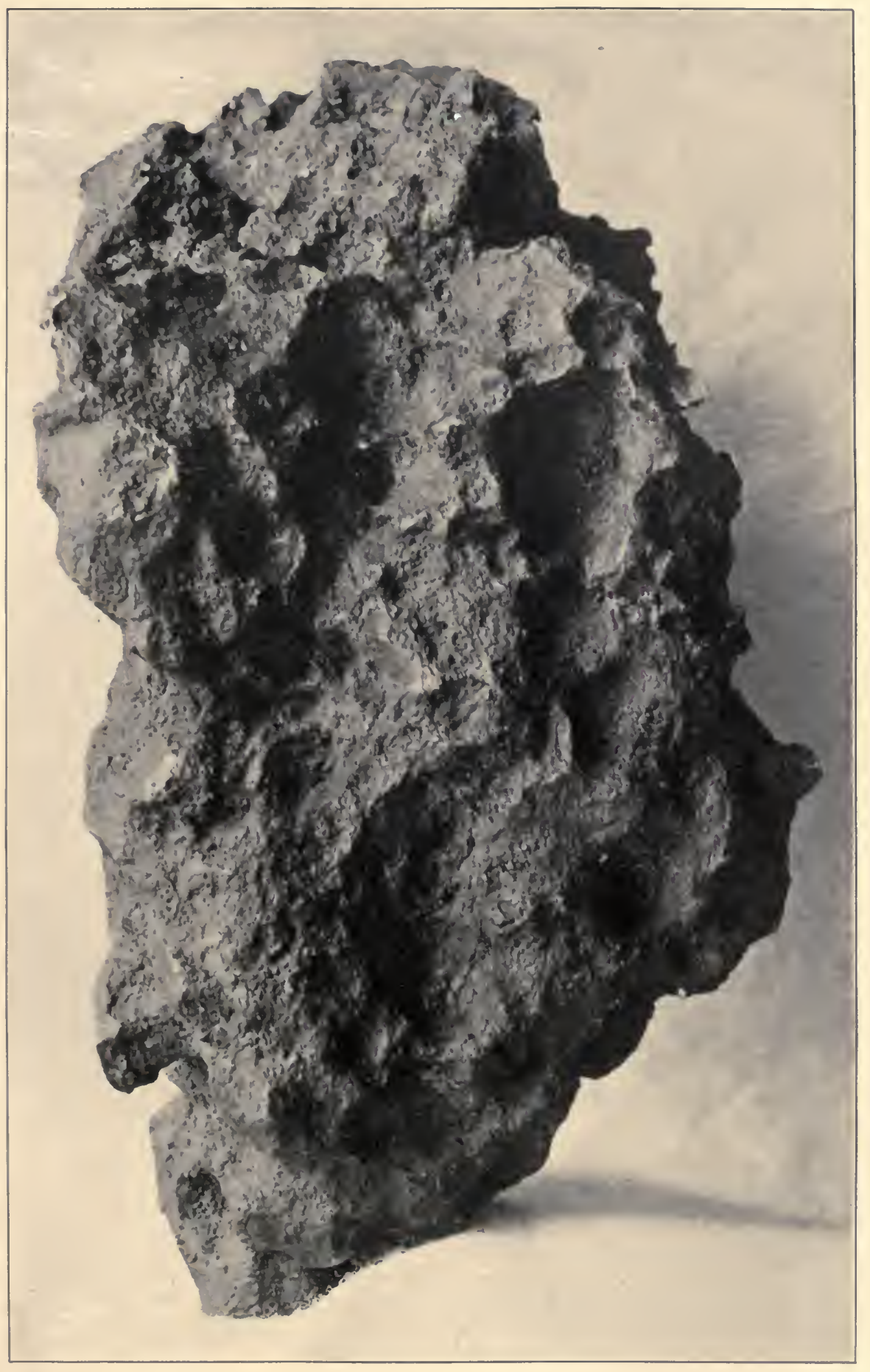

South Bend meteorite. View of base, $X \%$. 
LIBKAKY

UNIVERSIIY UF ILLINUIS

Ufturin! 


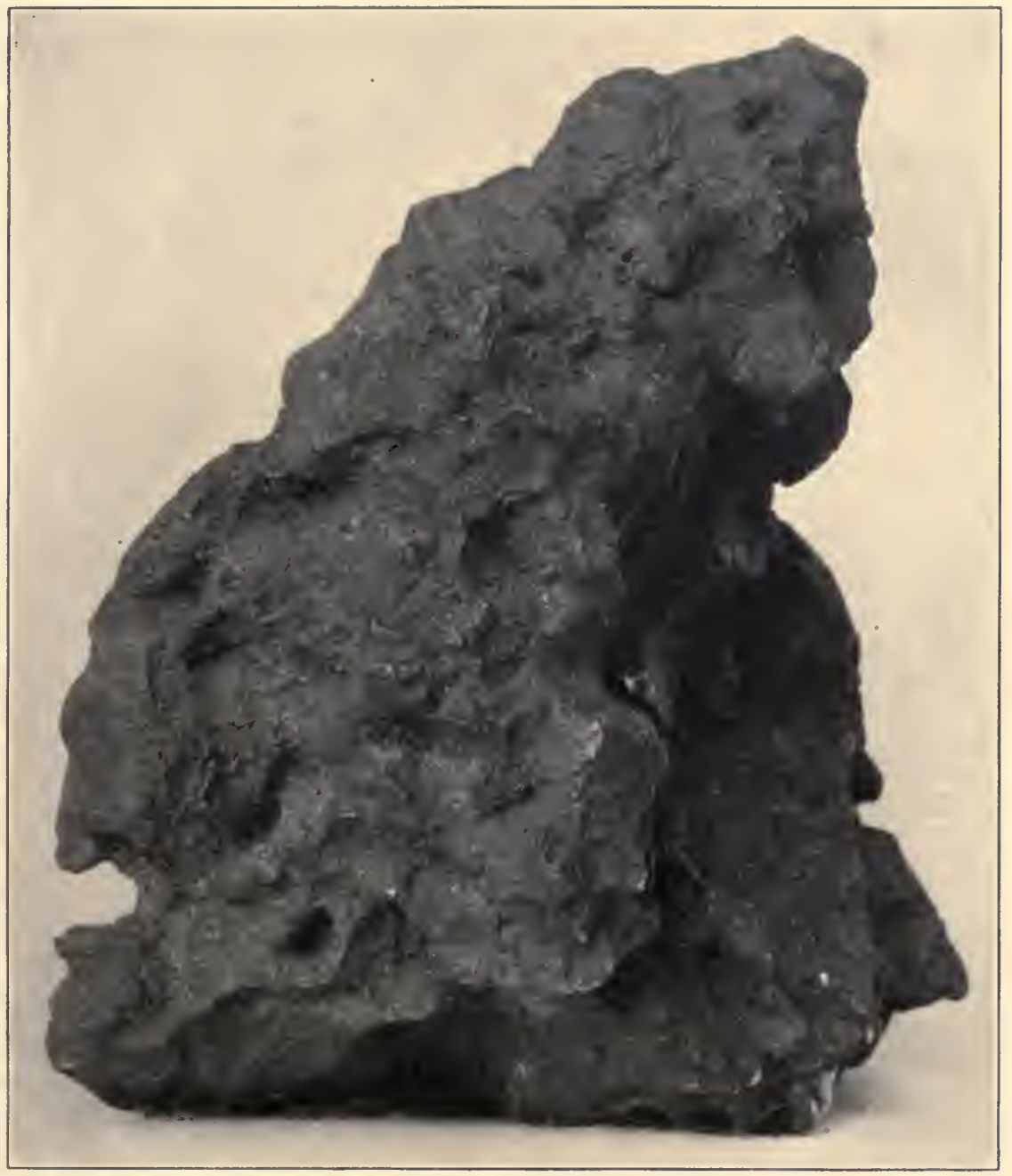

South Bend meteorite. End view, $\times \pi /$. 
LIBRARY

UNIVERSITY OF ILLINOIS

URBA:A 


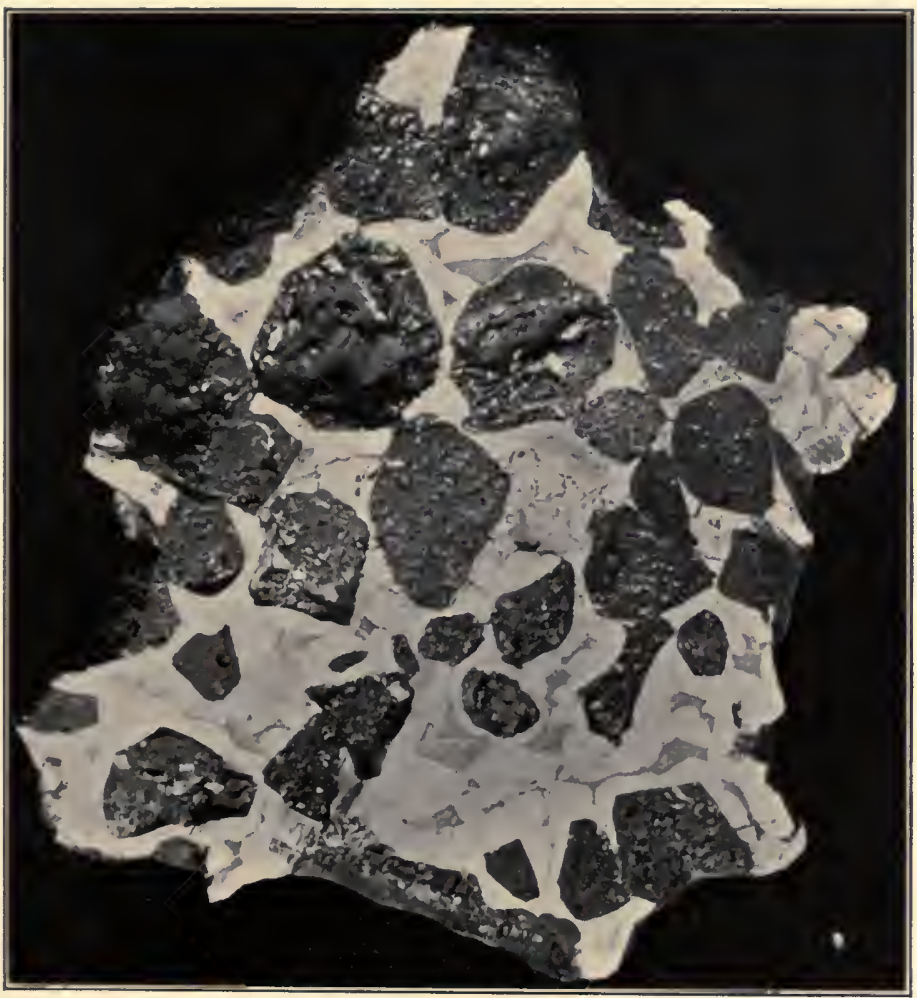

Etched section of South Bend meteorite, showing arrangement of nickeliron and chrysolite. The light portions are nickel-iron, the dark chrysolite, $\times \%$. 


$$
\text { - }
$$

LIBRARY

UNIVERSIIY OF ILLINOIS UPEAMA 


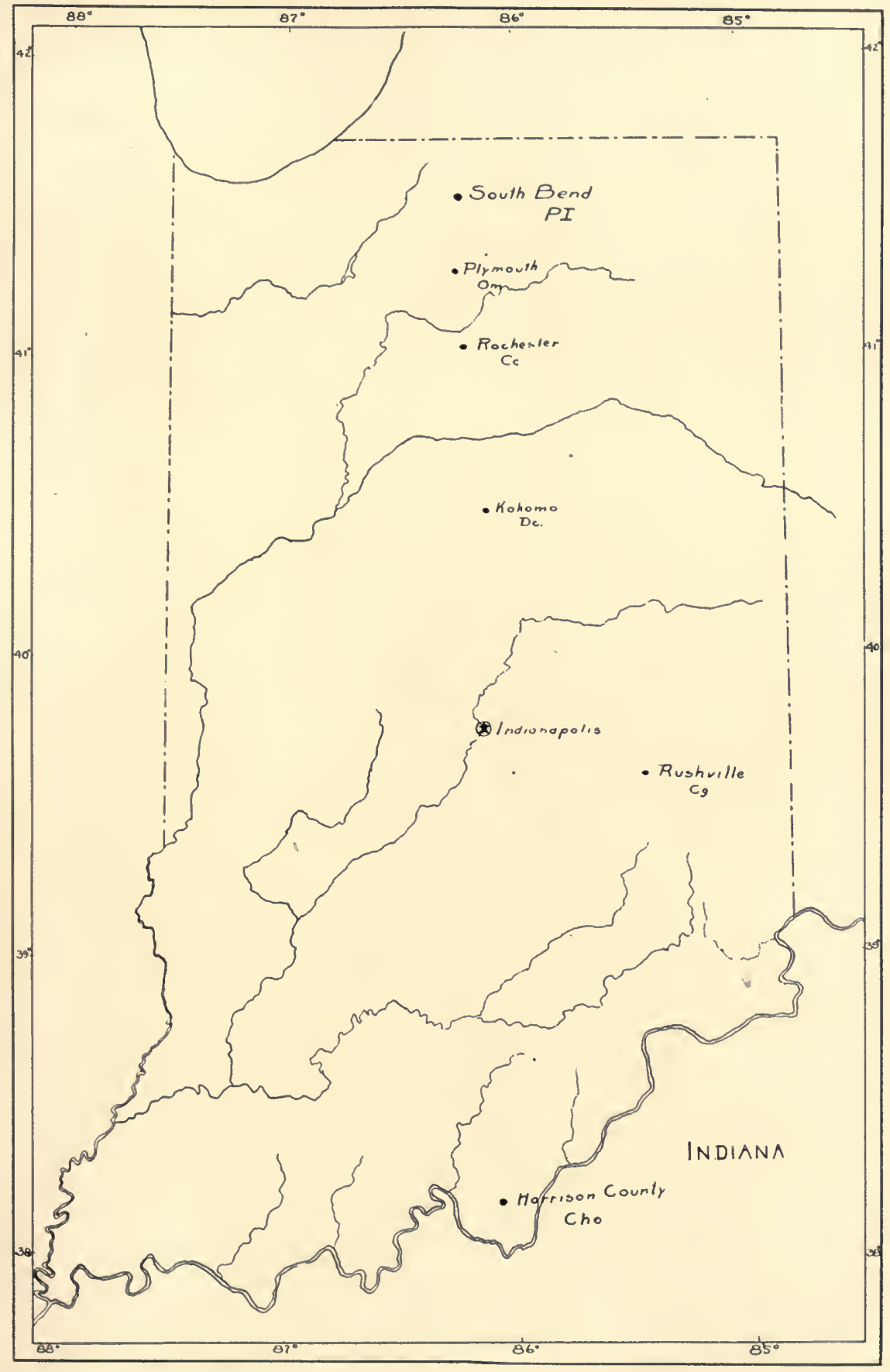

Map of Indiana, showing location of known meteorite falls. 


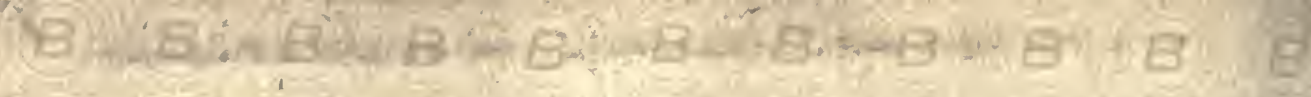

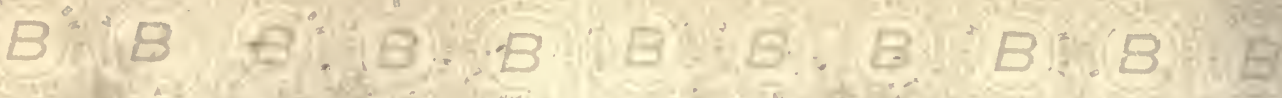

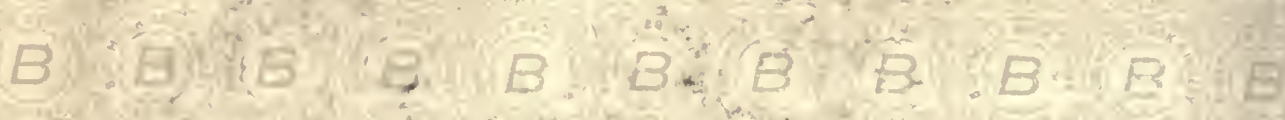
$(B) B, B+B$ B $B$, B B B. B

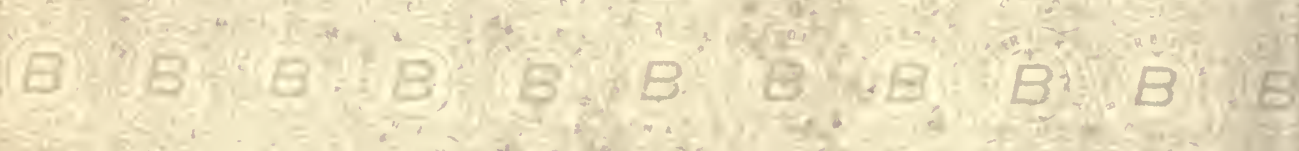
B B $\theta$ B a B B $B$ B B B Q B B B, B. B B B B B $B, B=B, B=B$ B B B B (B) $B, B=B, B \quad B \quad B=B$ B B $B$ B $B$ (B) B B B B B B B B. B B B $B$ B
B. $B$
3. $B=B^{\prime}=1$

B
$B^{\prime} B$
B
B)

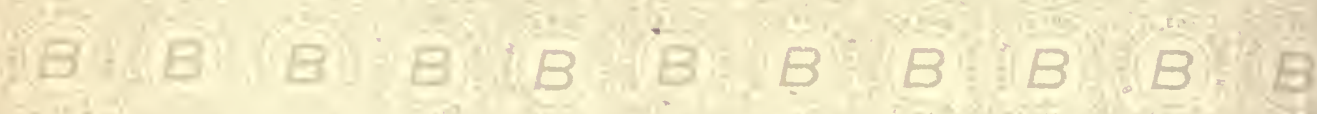

(B) $B$ B B B B B) B B B B

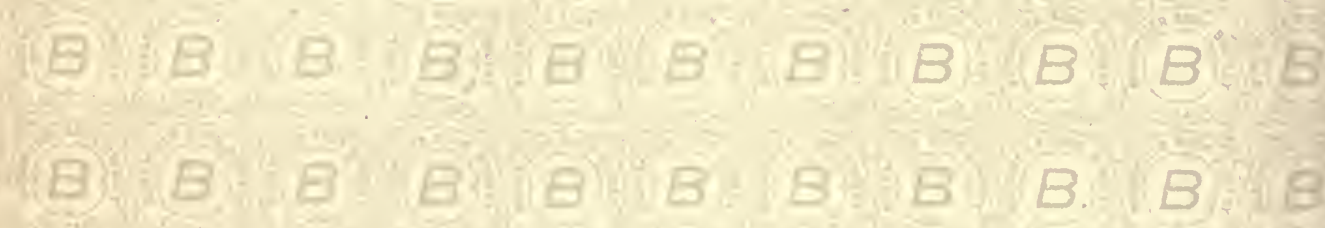

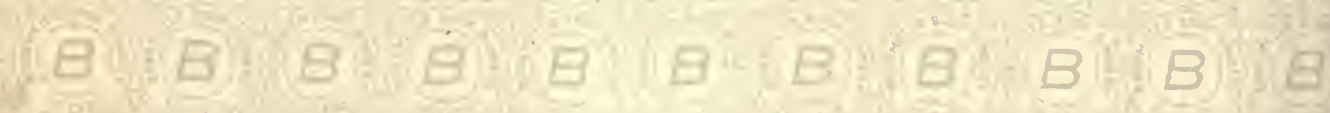

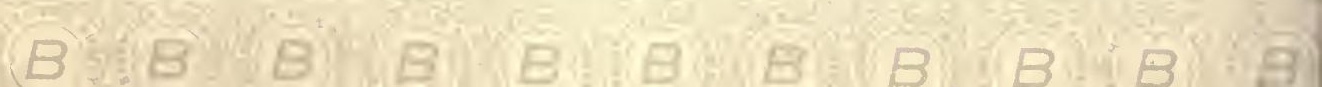




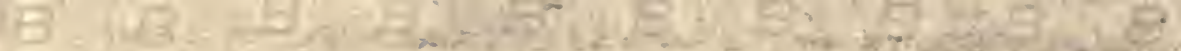

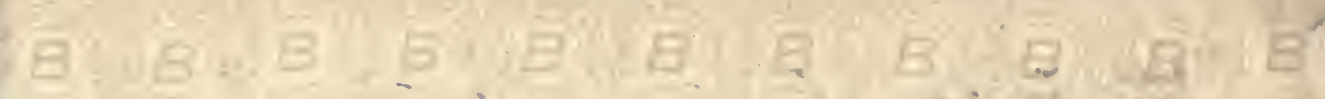

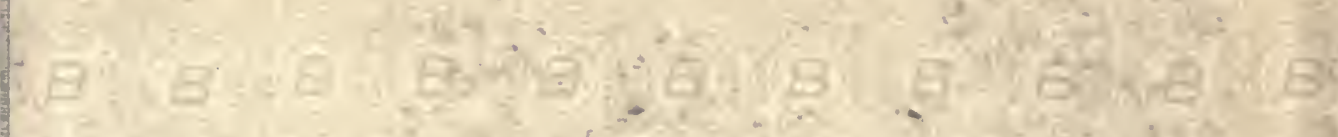
B) a $B$ is

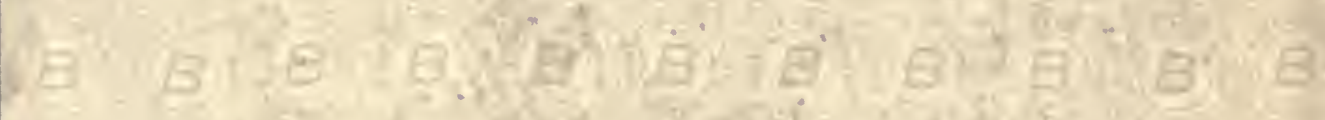

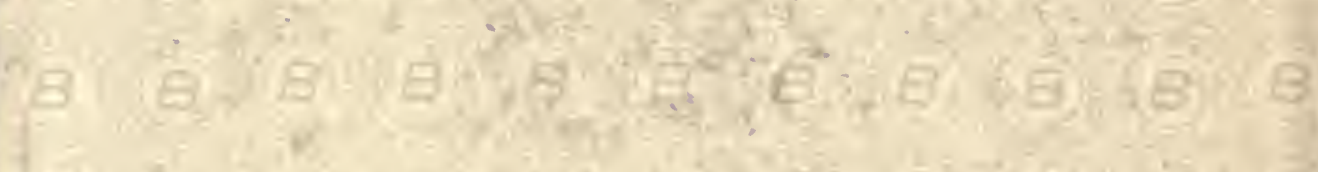

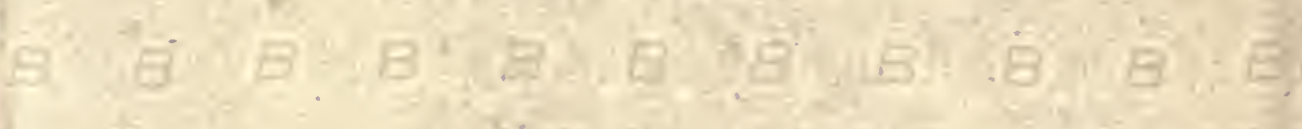

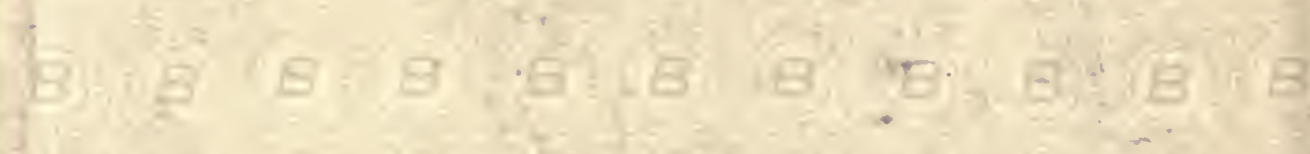
(7) $\bar{a}-\beta=\theta \cdot \beta=\beta=\theta \cdot \beta \cdot \theta$ E)

B)

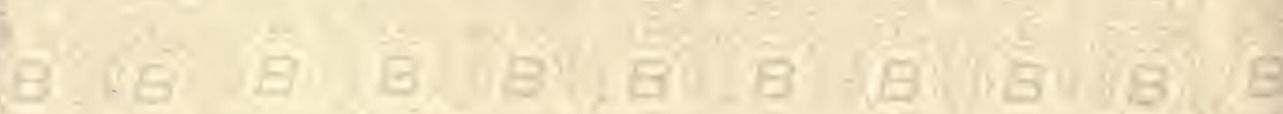

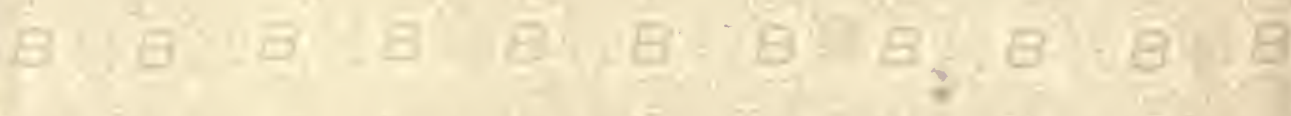

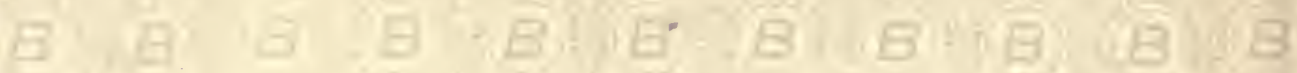

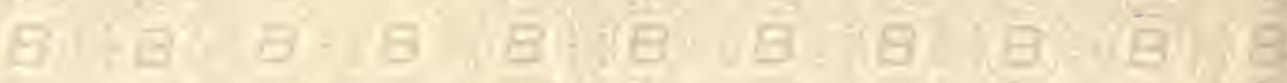

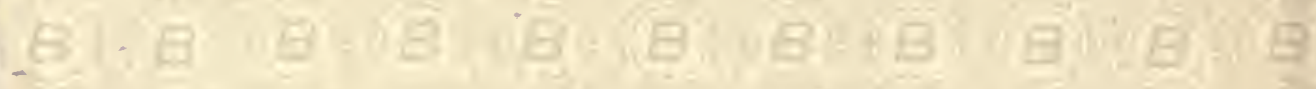

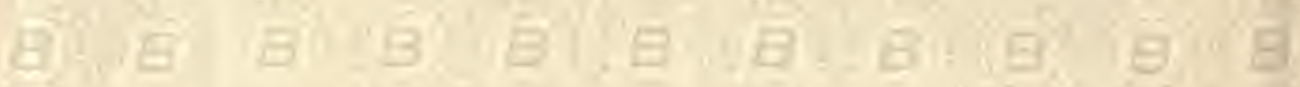

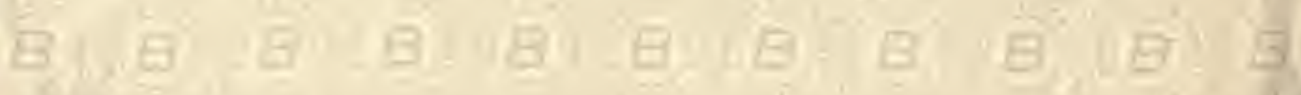

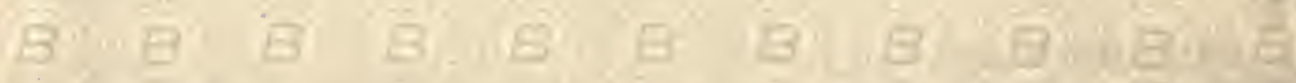


